\title{
Education Policy and Ethnic Relations in Malaysia: The Socio-Economic Perspectives
}

\author{
Mohamad Zaini Bin Abu Bakar \\ School of Social Sciences, Universiti Sains Malaysia \\ 11800 Minden, Penang Malaysia \\ Email: zainiab08@gmail.com
}

\section{Doi:10.5901/jesr.2014.v4n2p138}

\begin{abstract}
In Malaysia, as well as other countries, a national education system and a common language has become one of the most important cultural elements by which diverse culture groups can come together. It can form the foundation for a Malaysian national identity. In fact, the early move had been made before independence particularly through two reports, i.e. the Razak report and the Rahman Talib report. According to the Razak report 1956; "The ultimate objective of education policy in this country must be to bring together the children of all races under a national education system in which the national language (Malay language) is the main medium of instruction". Moreover, from a different point of view, we may argue that apart from the objective of unification, there was also an underlying economic motive in choosing Malay as the national language. The aim was stated by the Barnes Committee's Malay Education Recommendation of 1951 which wanted to encourage and enable the Malay community to occupy its rightful place in the mixed society of Malaysia. The manifestation of economic motives in the educational realm are reflected from the educational inequalities in which the Malays feel they had historically and at present an unfavoured position against the non-Malays who were far advanced. Policy makers and conflict management scholars have devoted a great deal of energy to try to explain the situation and the way this type of conflict can be remedied. Within the framework of socio-cultural dimension language and national education are important elements of the problem of Malaysian social and political system. Therefore the objective of this paper is to determine and to analyse the link between education and socio-economic factors, particularly where the language of instruction is concerned, has made education an 'emotional and contentious' issue in ethnically divided Malaysian society.
\end{abstract}

Keywords: Education Policy, National Language, Ethnic Relations, National Unity, and Conflict Management.

\section{Introduction}

"Education plays a central role in any country's pursuit of economic growth and national development. There is no better predictor of a nation's future than what is currently happening in its classrooms. In today's global economy, a nation's success depends fundamentally on the knowledge, skills and competencies of its people. It is no surprise that nations with higher education levels tend to enjoy greater economic prosperity. Education is also fundamental to nation building and unity. It provides individuals with the opportunity to improve their lives, become successful member of the community and active contributors to national development." (Malaysia Education Blueprint 2013-2025).

Before independence, the education system in Malaysia according to Milne and Mauzy (1986) can be divided into three tiers. Firstly, the most remarkable consisted of English-language primary and secondary schools, attended mostly by the children of the Malay aristocracy and wealthy urban Chinese and Indians. According to M.Bakri Musa (2013) there was the attitude of Malay parents who thought sending their children to English schools was tantamount to turning them into white man and, horror of horrors, Christians. Secondly, the secular Malay-medium primary school system, which the British established and supported (they also recognised and assisted the Malay-Arabic Quranic schools). The aim of this kind of school was to keep rural Malay youth as peasants. There is no secondary Malay schools system. Finally, the third tier was composed of vernacular Chinese and Indian (Tamil) schools. The Chinese established, oversaw, and financed their own primary and secondary schools.

Apart from the difference of the medium of instruction, the education system was also characterised by disparity in many aspect such as curriculum, syllabus and orientation. Such a situation was unhealthy for the future of Malaysian society. The link between education and socio-cultural factors, particularly where the language of instruction is concerned, has made education an 'emotional and contentious' issue in ethnically divided Malaysian society (Milne and Mauzy 1986). 


\section{Education and Socio-Economic Perspectives}

With regard to the above discussion, in the postindependence period we witness a crucial change that the government has made in the education programmes. In Malaysia, as well as other countries, a national education system and a common language has become one of the most important cultural elements by which diverse culture groups can come together (Wan Hashim, 1983, Enloe, 1968). It can form the foundation for a Malaysian national identity. In fact, the early move had been made before independence particularly through two reports, i.e. the Razak report and the Rahman Talib report. According to the Razak report 1956;

"The ultimate objective of education policy in this country must be to bring together the children of all races under a national education system in which the national language (Malay language) is the main medium of instruction, though we recognise that progress towards this goal cannot be rushed and must be gradual" (Report of The Education Review Committee, 1960).

Furthermore, under the independence constitution of 1957, Malay was made the national language, with English to remain in continued official use. In this regard, John Lowe (1960) argued that under the socio-cultural dimension, the non-Malays are on the defensive and the Malays on the offensive. However, the leaders of the Alliance party, in 1956 reached a consensus and agreed to the Education Act of 1957 under which;

(1) each ethnic community to conduct its own schools using its own language for teaching;

(2) because Malay is the national language, the Chinese and Indians schools must teach Malay as a subject;

(3) the approach in history, geography and other textbooks must be a Malaysian, not a Chinese or Indian one.

The endorsement of the above report by the leaders of the Alliance party through the process of musyawarah (or the consensus-seeking approach) indicated that the use of the Malay language as a tool of unification has been recognised officially ${ }^{1}$ (without putting in jeopardy the use of other languages).

Moreover, from a different point of view, Enloe (1968) and Wan Hashim (1983) argued that apart from the objective of unification, there was also an underlying economic motive in choosing Malay as the national language. The aim was stated by the Barnes Committee's Malay Education Recommendation of 1951 which wanted to encourage and enable the Malay community to occupy its rightful place in the mixed society of Malaya. The manifestation of economic motives in the educational realm are reflected from the educational inequalities in which the Malays feel they had historically and at present an unfavoured position against the non-Malays who were far advanced.

Manifestation of the statistics of enrolment at the higher learning institutions made the Malays fear for their future in their own country. For instance, at the University of Malaya, enrolment in 1966-1967 showed that 70 percent was nonMalay, and furthermore, the faculties of engineering, science, and medicine were $98 \%, 93 \%$ and $84 \%$ non-Malay respectively. At the University of Technology of Malaysia (formerly The Technical College) in Kuala Lumpur enrolment was 90 percent non-Malay (Esman 1972).

Therefore, after the May 13th, 1969 riots, the ruling party Alliance (which is led by the UMNO) was insistent that education would more fully reflect the intended Malay basis of society. This idea had multiple objectives, among other things to promote cultural unity, as well as to provide the device for Malays to "catch up" in education and economic pursuits (Milne and Mauzy, 1986). Gradually, beginning in July 1969, the government implemented the use of the Malay language as the main medium of instruction in all types of government-aided schools. To enhance this drive and to educate the Malays, government formulated the policies of quotas and scholarships, for university enrolment. Furthermore, government also established a number of universities to meet those objectives. The aftermath of this action was that Malay enrolment at tertiary institutions increased from about 20 percent in 1962 - 64 to more than 65 percent in 1975 (Milne and Mauzy, 1986).

In response to the above move the non-Malays, particularly the Chinese and Indians, feel their cultural heritage has to be maintained. To some extent the defenders of Chinese education contend that its "essence" (e.g., socialisation into Chinese culture) can never be captured in another setting, an education. Since the government is busy remedying the Malays' backwardness, various Chinese groups successfully promoted the conversion of Chinese secondary schools

\footnotetext{
1 This fact has been guaranteed by the government as firmly stated in the government official year book that the Malay Language is the National Language of the country. It was declared the official language in Malaysia in 1967 following the passing of the National Language Act by Parliament. The government promotes the use of the national language to foster national unity. An effective way of developing the national language is by making it the medium of instruction in schools and the institutions of higher learning in the country, besides being the official language in government administration. However, the people are free to use their mother tongue and other languages. English as the second language is widely used in business.
} 
to independent status to resist the conversion to Malay. The certificates from these schools have strong economic backing recognised by the Chinese business network, by Taiwan, and by some Western universities. Likewise, according to the study by Milne and Mauzy (1968),

\begin{abstract}
"there were record enrolments in Chinese primary schools in 1970s (specifically, a 21 percent upsurge in 1971 - 1978). This trend has continued despite the fact that facilities and qualified staff are lacking; indeed, the Democratic Action Party (the Chinese leading opposition party) in 1984 accused the government of ignoring the needs of Chinese primary schools in order to lower their effectiveness preparatory to converting them. Another decade-long Chinese effort was directed to the establishment of an independently financed Chinese-medium Merdeka University or (independent university). This effort was finally defeated when the Malaysian High Court ruled in late 1981 that it was "not expedient" in the national interest, and a subsequent appeal was rejected".
\end{abstract}

More over, according to Preliminary Report of the Malaysia Education Blueprint 2013-2025

"the proportion of Chinese students enrolled in National Type (Chinese) Schools increased from 92\% in 2000 to $96 \%$ in 2011. The shift for Indian students was even more dramatic, showing an increase from $47 \%$ to $56 \%$ enrolment in National Type (Tamil) School. As such, 90\% of students in National Schools are now ethnically Malay."

As has been emphasised earlier, socio-economic status is one of the important element in the educational realm. This is particularly relevant to the case of the inter-ethnic issue in Malaysia. Hirshman (1974) notes that education is usually considered as the 'imparting of greater skills or job qualifications.' Under these circumstances Hirshman (1974) continued that education is one of the parameters for social mobilisation.

According to Esman (1972) and Chopra (1974), Malay political, professional, and intellectual leaders fear for that Chinese economic dominance is reinforced by a growing dominance in the modern technologies, which are a complementary source of social power. Some Malays ask whether their control of government will be sufficient to counteract the rapid growing Chinese power in education and in the modern economy and whether, in addition to their efforts to foster Malay entrepreneurship and educational opportunity, direct government intervention is required to correct these imbalances, even at the risk of reduced efficiency and lower rates of economic growth.

\title{
3. Education and Restructuring the Society
}

This measure aims to avoid the identification of ethnicity with particular forms of economic activities as well as residential location. The plan outlines policies and programmes to 'modernise rural life'2, encourage a rapid and balanced growth of urban activities, provide improved education and training programmes at all levels, and above all ensure the creation of a Malay commercial and industrial community in all categories and at all levels of operation in order that within one generation Malays and other indigenous people can be full partners in the economic life of the nation. The measures to promote and increase Malay participation in commercial and industrial community had been done through direct government intervention and control. In this regards, Lee Hock Guan (2013) argue, the government has also continued to award student scholarships and loans on a largely ethnic-based income-blind basis, including through the National Higher Education Fund Corporation (NHEFC), Public Service Department (PSD) and especially Majlis Amanah Rakyat (or the Council Trust of the indigenous People).

Further, the government established new urban centres in the less developed areas by introducing industries and other facilities. Educational programmes were launched aimed at enabling Malays and other indigenous people to enter commerce and industry at the technical, professional, executive and managerial levels. The government had encouraged non-Malay firms and foreign owned enterprises to provide expanded opportunities for Malay participation as well as enable them to be given training at all levels. Particular arrangements were also planned for joint ventures between Malays and non-Malays and others in this area. By this means it is hoped that the expertise, experience, and markets of the established organisations will be made available to the fledgling Malay firms (Foreign Affairs Malaysia,1971).

In the further development, the role of education in raising productivity and income level has long been recognised.

\footnotetext{
2 Under this programme the government is not suggesting the rural sector be neglected, but the old subsistence rural economy must go. It must be transformed and modernised. According to Ghazali Shafie, thought should be given to organising the various rural areas and running them as so many different corporations with the land as capital in the corporation. This would promote large scale planned mechanised farming and the profits would go back to the farmer as it would to any shareholder of a company in proportion to the land which he/she has put at the disposal of the corporation.
} 
As such, Ragayah (2013) emphasise that the New Economic Policy focused on education as a means to eliminate poverty and restructure society. This objective was to be attained through the development of appropriate education and training programmes to raise the supply of trained manpower and direct incentives as well as administrative measures to boost their participation in the modern sector. While the Chinese and Indians also advanced in their educational attainment, the two decades of the New Economic Policy saw a tremendous growth of Malays being educated at all levels - primary, secondary and tertiary - and in all fields. Educational programmes, including university enrolment quotas, scholarship and other educational subsidies, helped Malays improve their wage-earning capacity, which led to a reduction in poverty incidence.

A firm target was set that by 1990, Malays should own and operate 30 percent of the modern commercial and industrial sectors. Malay ownership and control of share capital was to rise from 2 percent in 1970 to 30 percent in 1990, the non-Malay share from 23 percent to 40 percent and the foreign share was to be reduced from 62 percent to 30 percent (Datar, 1983). In order to achieve this target the government was fully aware of the problems facing it in the implementation of the programmes and projects, therefore, the government established a special unit - the Implementation, Coordination and Evaluation Unit (ICEU) - which is working directly to monitor the progress in the implementation of the said plan (Foreign Affairs Malaysia, 1971).

Although the role of education policy as a tools in the restructuring of the employment pattern so as to reflect the ethnic composition of the population has made a significant achievement, imbalances in employment continue to exist with regard to the specific restructuring targets particularly at the professional and managerial as well as technical and skilled occupations. According to the report of Second Outline Perspective Plan (OPP2), despite the fact that the Malay employment in the manufacturing sector has improved as indicated above, they were more concentrated at the lower ranks of occupation. Moreover, the Malay accounted for only about 26 per cent of the total professional and managerial employees and about 36 per cent of the total technical and supervisory employees in the sector. Generally, in the professional and technical category almost half of the 60.3 per cent Malay employments were in the nursing and teaching professions. In certain high-paying registered professional jobs such as architects, accountants and doctors, the Malay only made up 29 per cent of the total in 1990. In the administrative and managerial category, the Malay employment was about 33.3 per cent while the Chinese dominated with about 58.7 per cent and 5.3 per cent for the Indians.

\section{Conclusion}

Based on the scenario above, the policy of preference, which has been given a structured expression in the form of the education policy in general does not aim at ethnic domination or supremacy. In this regards, Cheng Taik emphasise that, it merely seeks on the one hand to overcome the historical backwardness of the Malays and to lift them up to a level at which they will be able - without further handicap - to compete equally with the immigrant ethnicity while on the other hand the government has guaranteed under the Federal Constitution that no particular group will experience any loss or feel any sense of deprivation. For instance, in the Federal Constitution, Article 153 contains safeguards for the legitimate interests of the Chinese and other ethnic groups. Whilst preference is afforded to the Malays in trade, industry or education, it is not intended to oust the existing participants. As a result, the education policy practically transformed the socio-economic structure of the nation.

\section{References}

Buku Rasmi Tahunan (Government Official Year Book), 1994

Cheng Teik, Goh, (1989), Racial Politics in Malaysia, FEP International co.Itd., Petaling Jaya, Selangor, Malaysia.

Cheng Teik, Goh, (1978), Integration in a Plural Society: the Chinese in Malaysia,

Chopra, Pran, (1974), "Malaysia's Strategy for Survival", in Pacific Affairs, vol. 47, no. 4, 1974 - 1975

Datar, Kiran Kapur, (1983), Malaysia Quest for a Politics of Consensus, Vikas Publishing House, New Delhi, India.

Esman, Milton J. (1972), Administration and Development in Malaysia, Institution Building and Reform in a Plural Society, Cornell University Press, Ithaca and London.

Ghazali bin Shafie, (1993), "Conflict Resolution: The Malaysian Experience", paper presented at the workshop on Conflict Management and Conflict Resolution held in Kuala Lumpur, August, 7 and 8, 1993.

Ghazali bin Shafie,(1985), Rukunegara: A Testament of Hope (Selected Speeches), Kuala Lumpur, Malaysia.

Ghazali bin Shafie (1978), Malaysia: Nilai Politik \& Budaya (Malaysia: Cultural and Political Values), Dinamika Kreatif, Kuala Lumpur.

Ghazali Bin Shafie, "The Way Ahead", in Foreign Affairs Malaysia, vol. 5, no. 3, September, 1972.

Government of Malaysia, Second Malaysia Plan, (1971), Government Press, Kuala Lumpur,

Government of Malaysia, Foreign Affairs Malaysia, vol.4., no.3, September, 1971. 
Lee Hock Guan (2013), Racial Citizenship and Higher Education in Malaysia, in Gomez and Johan Saravanamuttu (eds), (2013), The New Economic Policy in Malaysia : Affirmative Action, Ethnic Inequalities and Social Justice, ISEAS Publishing, Singapore.

Lowe, John, (1960), The Malayan Experiment, Fabian Society, London.

Milne R.S. (1967), The Government and Politics of Malaysia, Boston, Houghton Mifflin Co.

Milne R.S., and Mauzy, Diane K.,(1986), Malaysia: Tradition, Modernity and Islam, Westview Press, Boulder and London.

M.Bakri Musa (2013), Liberating The Malay Mind, ZI Publication Sdn. Bhd, Petaling Jaya, Selangor.

Preliminary Report of the Malaysia Education Blueprint 2013-2025

Ragayah Hj. Mat Zin, (2013), The New Economic Policy and Poverty Eradication in Malaysia, in Gomez and Johan Saravanamuttu (eds), (2013), The New Economic Policy in Malaysia : Affirmative Action, Ethnic Inequalities and Social Justice, ISEAS Publishing, Singapore.

The Strait Echo Press Sdn.Bhd, Kuala Lumpur, Malaysia, 1978.

Wan Hashim Bin Wan Teh, (1983), Race Relation in Malaysia, Heinemann Educational Books (Asia) Ltd., Kuala Lumpur. 